\title{
First record of Omura's whale, Balaenoptera omurai, in Sri Lankan waters
}

\author{
Asha de Vos
}

\begin{abstract}
An unusually coloured, small baleen whale was documented off the southern coast of Sri Lanka in February 2017 during routine field surveys. Based on five distinct morphological characteristics including jaw asymmetry, presence of a prominent central rostral ridge, blaze on right side, asymmetrical chevron on left and right sides and a strongly falcate dorsal fin the individual was positively identified as an Omura's whale (Balaenoptera omurai). This discovery represents the first confirmed sighting of Omura's whale in Sri Lankan and therefore central Northern Indian Ocean waters.
\end{abstract}

Keywords: Northern Indian Ocean, Sri Lanka, Omura's whale, Sri Lanka, Distribution, Balaenoptera omurai

\section{Background}

Originally misclassified as a pygmy form of Bryde's whale (Balaenoptera edeni) in the 1970s, the Omura's whale has since been described as a distinct baleen whale species of the family Balaenopteridae (Wada et al. 2003). Sasaki et al. (2006) showed that in fact the Omura's whale represents an ancient independent lineage that diverged around 17 million years ago within the Balaenopteridae.

This species is currently confirmed from the northeastern and South Atlantic, western Pacific and Indian Ocean. The records from the Indian Ocean are largely from the eastern Indian Ocean and more recently, with the discovery of a resident population of Omura's whales in Madagascar, the southwestern Indian Ocean and one from Iran in the northwest Indian Ocean.

This discovery represents the first confirmed documentation of Omura's whale within Sri Lankan waters and therefore the first from the central Northern Indian Ocean.

\section{Results}

An Omura's whale was photographed on 5 February 2017 during routine blue whale photo-identification surveys. The solitary individual was documented approximately $7 \mathrm{~km}$ from shore in water between 55-65 m deep (Fig. 1). As the research vessel was switched off, the

\section{Correspondence: ashadevos@gmail.com}

Oceanswell and The Sri Lankan Blue Whale Project, 131 W.A.D. Ramanayake Mawatha, Colombo 2, Sri Lanka animal approached the boat enabling a series of photographs highlighting a number of key morphological characteristics to be taken. These characteristics include, jaw asymmetry (Fig. 2a and b), prominent single central rostral ridge and not three as found in B. edeni (Fig. 2b), blaze on right side (Fig. 2c), asymmetrical chevron on both right and left sides (Fig. 2c and d) and falcate dorsal fin (Fig. 2e). These characteristics allow us to morphologically distinguish this individual from Bryde's whales that are commonly recorded in Sri Lankan waters.

The following morphologically diagnostic features enabled the identification of this individual as an Omura's whale (Fig. 2).

1. Jaw asymmetry As described by Cerchio et al. (2015), this individual showed evidence of asymmetrical colouration of the lower jaws, with a darkly pigmented left jaw (Fig. 2 a) and lightly pigmented right jaw (Fig. 2 b).

2. Presence of a prominent single medial ridge The prominent rostral ridge and absence of pronounced lateral ridges (only lightly visible) enabled differentiation from the more commonly sighted Bryde's whale with central ridge and lateral ridges (Wada et al. 2003).

3. Presence of right side blaze As described by Cerchio et al. (2015) white pigmentation is more extensive on the right side of the body compared to the left. This individual 


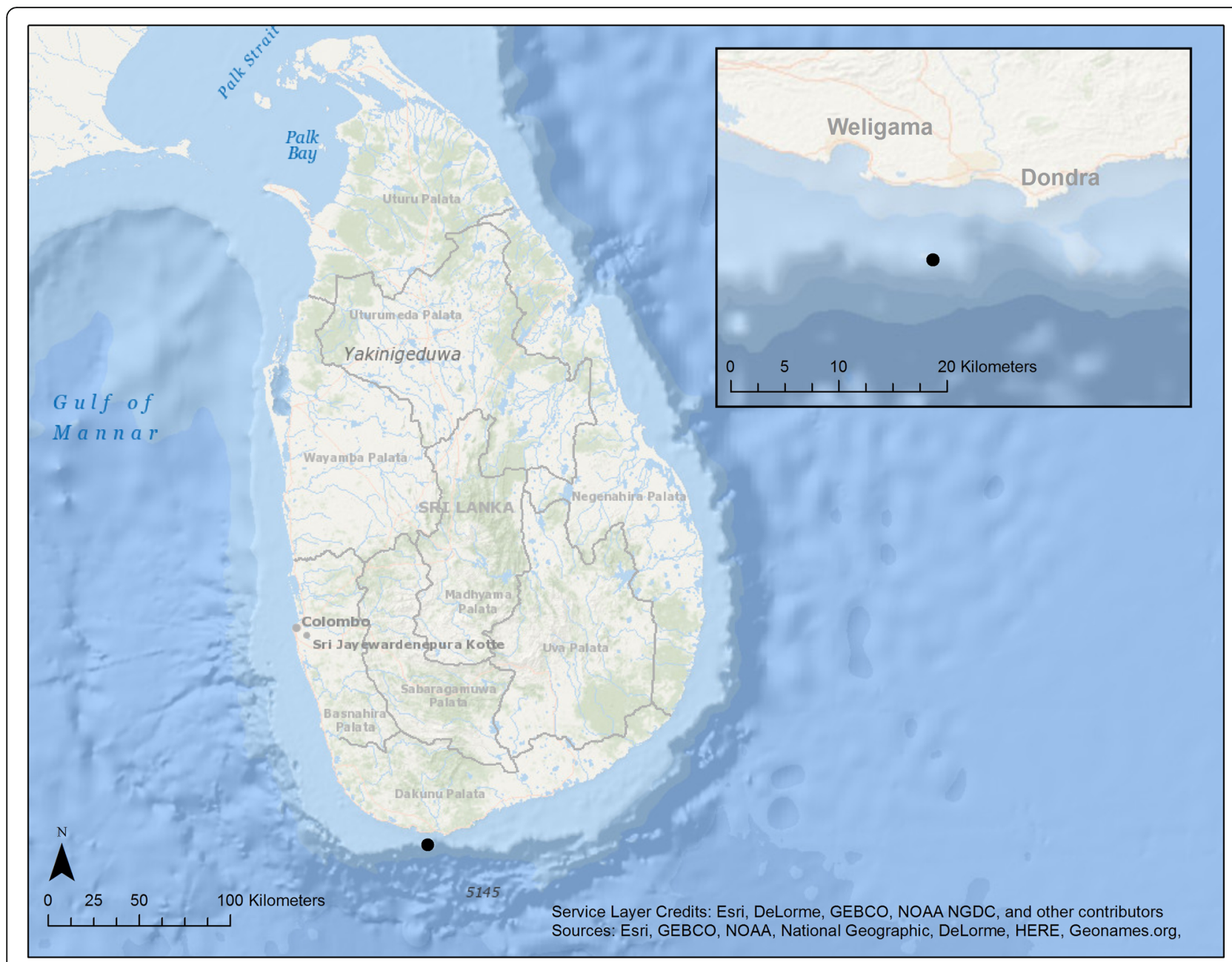

Fig 1 Map showing sighting location of Omura's whale off southern Sri Lanka encountered on 5 February 2017. Black dot on southern coast represents the location of the sighting, which was approximately $6.9 \mathrm{~km}$ offshore in water that was between 55-65 m deep

also showed evidence of a lightly pigmented blaze anterior to the eye only present on the right side and multiple dark stripes bisecting the blaze.

4. Asymmetrical chevron on both right and left sides Lightly pigmented chevron anterior to the dorsal fin evident on both sides but more pronounced on right side of the body, displaying a double-banded pattern also described by Cerchio et al. (2015).

5. Strongly falcate dorsal fin

The dorsal fin was pointed, strongly falcate and backswept (Wada et al. 2003; Cerchio et al. 2015; Jefferson et al. 2008; Ranjbar et al. 2016)

Apart from the distinguishing characteristics, this individual also possessed a mark that resembled a tyre mark on its left dorsal flank and an entanglement scar on the tip of its left rostrum. Both these markings appear to be made by external interactions and are not characteristics of this species.

\section{Discussion}

The morphological characteristics described through the photographs taken on 5 February 2017 provide evidence for the presence of Omura's whales in Sri Lankan waters and thereby the central Northern Indian Ocean. A previous record from Iran already indicated presence of this species within the western Northern Indian Ocean (Ranjbar et al. 2016). This is the only confirmed record of an Omura's whale in Sri Lankan waters to date. This is a new record within an expected range within which few sightings/records have previously been available.

The detailed description of the external features of this species provided by Cerchio et al. (2015) were useful for the identification of this individual within Sri Lankan waters. The key features of interest that enable us to discern between Omura's and Bryde's that are often recorded in these waters include the prominent dorsal ridge on the rostrum (Bryde's whales often have three head ridges; the central ridge is flanked by two lateral 

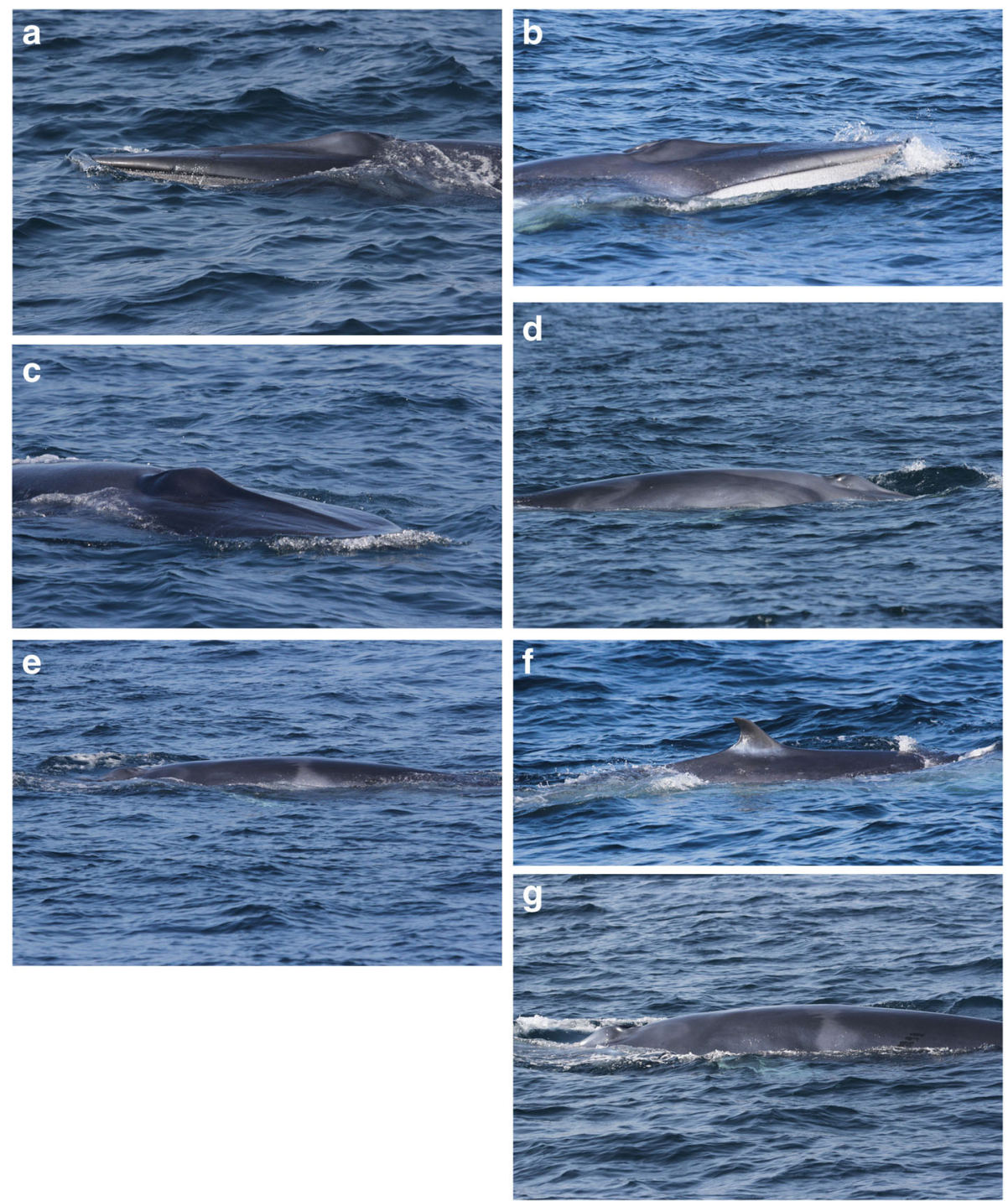

Fig 2 Omura's whale documented off southern Sri Lanka on 5 February 2017. The morphological characteristics captured in these images distinguish this individual from Bryde's whales that are commonly seen in Sri Lankan waters. These characteristics include; Jaw asymmetry with a left jaw being dark in colour compared to the $\mathbf{b}$ right jaw which is light in colouration; $\mathbf{c}$ prominent single ridge on rostrum and weak lateral ridges on each side; Chevron on $\mathbf{d}$ right (more prominent) and $\mathbf{e}$ left sides; and $\mathbf{f}$ strongly falcate dorsal fin. Other markings of note include $\mathbf{a}$ entanglement scar on left upper jaw and $\mathbf{g}$ 'tyre mark' on left dorsal flank

rostral ridges), body colouration (Bryde's whales are dark throughout their bodies), and the shape of the dorsal fin (which is small and falcate in relation to that of the Bryde's whale) (Yamada 2009).

The 'tyre' like markings observed on the left dorsal flank of this individual may represent attachment sites of a remora (Echeneidae) as speculated by Cerchio et al. (2015). Remoras are commonly seen attached on blue whales in Sri Lankan waters, but do not leave any visible markings of this nature likely due to a difference in the physical characteristic of the dermis (Cerchio, pers. Comm..).
This individual also showed evidence of an entanglement scar on the left side of its upper jaw indicating that this is a potential threat for this species in these waters. Because the range of this species is still unknown the threats they face are yet unclear making the documentation of this entanglement scar particularly important. Bycatch in local fisheries has been reported from Songkhla, Thailand (Adulyanukosol et al. 2012), and given its penchant for shallow water habitats, bycatch is likely a threat throughout its range (Cerchio et al. 2015). In Sri Lankan waters, ship-strike is the leading population-level threat to blue whales, followed by 
incidental catch which includes both entanglement and bycatch (de Vos et al. 2016). Given the smaller size of Omura's whales compared to blue whales it can be considered a particularly pertinent threat to this species in Sri Lankan waters.

The population of Omura's whales off northwest Madagascar was preferentially seen in water that was 4-202 m deep with SST between 27.4 and $30.2{ }^{\circ} \mathrm{C}$ (Cerchio et al. 2015). The sighting reported here was made in waters $55-65 \mathrm{~m}$ deep within $7 \mathrm{~km}$ of the coast providing further evidence that these whales prefer shallow shelf waters.

Cerchio et al. (2015) suggested that because extensive genetic sampling of Bryde's whale populations in the North Indian Ocean did not reveal evidence of $B$. omurai (Kershaw et al. 2013), the distribution of this species is discontinuous with the Madagascar population being potentially isolated from the eastern populations. However, this record from Sri Lankan waters and a previous record from Iran (Ranjbar et al. 2016) may provide some evidence of connectivity across their range.

Given the rarity of this sighting it is important to continue to monitor and record sightings of this species, document resightings of individuals across years and within seasons to estimate population abundance and define movements and ranges, clarify the distinction between Omura's and Bryde's whales to ensure accurate records and identify the threats faced by this species.

The images illustrate the characteristic features of this species and highlight the importance of field surveys and photo-identification work that enable the discovery and description of new species and provide opportunity to expand our knowledge of the marine mammals inhabiting our oceans. As such, please submit any images of Bryde's whales or Omura's whales from Sri Lankan waters, to the respective catalogues by contacting the corresponding author.

\section{Conclusions}

This is the only confirmed record of Omura's whales from Sri Lankan waters and the central Northern Indian Ocean. It is a new record within an expected range within which few sightings/records have previously been available and may provide some evidence of connectivity with the populations in the eastern Indian Ocean.

\section{Acknowledgements}

All research reported in this manuscript was conducted under a Department of Wildlife Conservation, Sri Lanka permit (number WL/3/2/1/18). I would like to acknowledge Robert Brownell Jr. and Salvatore Cerchio for help in confirming the sighting. Further, I wish to thank my field team Ariesha Wikramanayake, Ben Yexley and Rosalind Bown for their assistance through the field period. Finally, I wish to thank Andrew Lewin for help in producing the map indicating the location of sighting.

\section{Funding}

Fieldwork was conducted using funds from a National Geographic Emerging Explorer grant.

\section{Availability of data and materials}

The datasets used and/or analysed during the current study are available from the corresponding author on reasonable request.

\section{Authors'contributions}

$\mathrm{AdV}$ conducted the fieldwork, analysed the photos and wrote the paper.

\section{Competing interests}

The author declares that she has no competing interests.

Consent for publication

Not applicable.

Ethics approval and consent to participate

Not applicable.

\section{Publisher's Note}

Springer Nature remains neutral with regard to jurisdictional claims in published maps and institutional affiliations.

Received: 27 April 2017 Accepted: 5 June 2017

Published online: 13 June 2017

\section{References}

Adulyanukosol K, Thongsukdee S, Passada S, Prempree T, Wannarangsee T. Bryde's whales in Thailand. Bangkok, Thailand: Aksornthai Printing Co.; 2012.

de Vos A, Brownell Jr RL, Tershy BR, Croll DA. Anthropogenic threats and conservation needs of blue whales, Balaneoptera musculus indica, around Sri Lanka. J Mar Biol. 2016:2016:12.

Cerchio S, Andrianantenaina B, Lindsay A, Rekdahl M, Andrianarivelo N, Rasoloarijao T. Omura's whales (Balaenoptera omurai) off northwest Madagascar: ecology, behaviour and conservation needs. R Soc Open Sci. 2015;2:150301.

Jefferson TA, Webber MA, Pitman RL. Marine mammals of the world: A comprehensive guide to their identification. Canada: Academic; 2008.

Kershaw F, Leslie MS, Collins T, Mansur RM, Smith BD, Minton G, Baldwin R, LeDuc RG, Anderson RC, Brownell Jr RL, Rosenbaum HC. Population Differentiation of 2 Forms of Bryde's Whales in the Indian and Pacific Oceans. J Hered. 2013;104:755-64.

Ranjbar S, Dakhteh MS, Waerebeek KV. Omura's whale (Balaenoptera omurai) stranding on Qeshm Island, Iran: further evidence for a wide (sub)tropical distribution, including the Persian Gulf. Journal of Marine Biology and Oceanography. 2016;5:1-9.

Sasaki T, Nikaido M, Wada S, Yamada TK, Cao Y, Hasegawa M, Okada N. Balaenoptera omurai is a newly discovered baleen whale that represents an ancient evolutionary lineage. Mol Phylogenet Evol. 2006:41:40-52.

Wada S, Oishi M, Yamada TK. A newly discovered species of living baleen whale. Nature. 2003;426:278-81.

Yamada TK. Omura's whale, Balaenoptera omurai. In: Ohdachi S, Ishibashi Y, Iwasa M, Saitoh T, editors. The Wild mammals of Japan. Kyoto, Japan: Shoukahoh Book Sellers and Mammalogical Society of Japan; 2009. p. 330-1.

Submit your next manuscript to BioMed Central and we will help you at every step:

- We accept pre-submission inquiries

- Our selector tool helps you to find the most relevant journal

- We provide round the clock customer support

- Convenient online submission

- Thorough peer review

- Inclusion in PubMed and all major indexing services

- Maximum visibility for your research 